INTERNATIONAL JOURNAL OF PUBLIC DEVOTION

e-ISSN: 2614-6762 dan p-ISSN: 2614-6746

Volume 3 Number 2. December 2020

This work is licensed under

a Creative Commons Attribution-NonCommercial 4.0 International License.

\title{
Penguatan UMKM Melalui Pemanfaatan Media Sosial dalam Meningkatkan Jangkauan Pemasaran Produk Handcraft Desa Babakanmulya Kuningan Jabar
}

\author{
Neni Nurhayati ${ }^{1}$ \\ Program Studi Akuntansi/Universitas Kuningan ${ }^{1}$ \\ Neni.nurhayati@uniku.ac.id ${ }^{1}$
}

Kata Kunci :

Media Sosial, UMKM, Pemasaran

\begin{abstract}
ABSTRAK
Permasalahan UMKM handcraft di Desa Babakanmulya adalah kesulitan dalam media pemasaran dan masih rendahnya kompetensi Sumber Daya Manusia (SDM) dalam memanfaatkan media sosial sebagai sarana dalam memasarkan produk handcraft. Adanya permasalahan tersebut menjadi perlu adanya sebuah pelatihan terkait optimalisasi penggunaan media sosial sebagai upaya memperluas jangkauan pemasaran produk. Tujuan pelaksanaan pengabdian kepada masyarakat ini adalah untuk memberikan pemahaman, pengetahuan dan wawasan mengenai optimalisasi penggunaan media sosial dalam upaya meningkatkan jangkauan pemasaran produk handcraft . Metode pengabdian yang digunakan yaitu ceramah, workshop, praktik, dan evaluasi kegiatan. Hasil dari pengabdian kepada masyarakat ini berupa terciptanya media promosi produk sebagai sarana pemasaran serta meningkatnya pengetahuan dan keterampilan pemilik UMKM dalam pemanfaatan media sosial sebagai strategi meningkatkan jangkauan pemasaran produk handcraft.
\end{abstract}

Keywords :

Social Media, MSMEs, Marketing

\section{ABSTRACT}

The problem of handcraft UMKM in Babakanmulya Village is the difficulty in marketing media and the low competence of Human Resources (HR) in utilizing social media as a means of marketing handcraft products. The existence of these problems requires a training related to the optimization of the use of social media as an effort to expand the product marketing reach. The purpose of this community service implementation is to provide understanding, knowledge and insight regarding the optimization of the use of social media in an effort to increase the marketing reach of handcraft products. The service methods used are lectures, workshops, practice, and activity evaluation. The result of this community service is the creation of product promotion media as a means of marketing as well as increased knowledge and skills of MSME owners in the use of social media as a strategy to increase the marketing reach of handcraft products. 


\section{PENDAHULUAN}

Desa Babakanmulya merupakan desa hasil dari pemekaran Desa Puncak Kecamatan Cigugur Kabupaten Kuningan Jawa Barat tahun 1984. Dilihat dari topografinya Desa Babakanmulya berupa pesawahan dan perbukitan. Masyarakat di Desa Babakamulya sebagian besar memiliki matapencaharian sebagai petani dan wiraswasta. Desa Babakanmulya merupakan salah satu desa yang berada di kaki Gunung Ciremai. Suasana perkampungan yang masih lekat dengan budaya gotong royong membuat desa ini menjadi lebih nyaman dan ditambah dengan pemandangan khas pegunungan yaitu hamparan sawah yang luas dan pertanian sayur yang segar akan memanjakan mata setiaporang yangakan mengunjungi desa ini. Namun tak banyak yang tahu tentang salah satu potensi yang ada di Desa Babakanmulya ini. Berdasarkan observasi awal yang telah dilakukan diketahui bahwa di Desa Babakanmulya terdapat UMKM berupa Handcraft. Desa ini merupakan satahsatu penghasil kerajinan tangan (Handcraf) kayu. Kerajinan yang dihasilkan dari Desa Babakanmulya ini salah satunya adalah patung kayu kuda khas.Tidak hanya membuat patung saja, tetapi mereka juga membuat seni pahat kayu lain seperti, gantungan kunci, piala dan berbagai jenis pahatan yang bisa di custom sesuai pesanan.

Dimasa pandemi seperti ini penjualan handcraft sangat menurun. Berdasarkan data dari pemerintah desa setempat salah satu permasalahan yang dihadapi oleh pemilik UMKM Handcraft adalah kesulitan dalam media pemasaran dan masih rendahnya kompetensi Sumber Daya Manusia (SDM) dalam memanfaatkan media sosial sebagai sarana dalam memasarkan produk handcraft. Jangkauan pemasaran selama ini hanya di sekitar Kabupaten Kuningan. Padahal di era teknologi yang semakin canggih sekarang ini, media sosial menjadi sangat berperan penting dalam mensukseskan pemasaran suatu produk. Adanya kondisi ini mengakibatkan jangkauan produk UMKM Handcraft sangat sempit sehingga omset tidak optimal yang berdampak pada pendapatan yang diperoleh UMKM tersebut juga tidak optimal.

Pemasaran suatu produk menjadi hal yang sangat penting dalam dunia usaha. Philip Kotler (1998) mengemukakan bahwa konsumen mempelajari merek-merek yang tersedia dari ciri-ciri nya sebagai informasi untuk mengevaluasi semua alternatif yang ada dalam menentukan keputusan pembelinya.

Menurut Sutisna (2001), "setidaknya ada dua kriteria evaluasi alternatif. Pertama, manfaat yang diperoleh dari membeli produk. Kedua, kepuasan yang diharapkan “.

Media sosial saat ini merupakan alternatif solusi yang bisa digunakan untuk memasarkan produk. 130 juta atau sekitar 49 persen penduduk Indonesia merupakan pengguna aktif media sosial (Anggraeni dalam Puspitarini, 2019). Media sosial merupakan sebuah medium di internet yang memungkinkan penggunanya untuk merepresentasikan diri dan melakukan interaksi, bekerjasama, berbagi, komunikasi dengan pengguna lain dan membentuk ikatan sosial secara virtual (Nasrullah, 2015:11).

Rendahnya kompetensi SDM dalam hal pengetahuan dan keterampilan menggunakan media sosial berdampak pada tidak optimalnya omset dari penjualan produk tersebut. Adanya permasalahan ini mengakibatkan perlunya sebuah upaya untuk dapat menjadi solusi dalam menjawab permasalahan tersebut. Oleh karena itu perlu dilakukan sebuah kegiatan berupa pelatihan kepada pemilik UMKM Handcraft terkait dengan optimalisasi penggunaan media sosial sebagai upaya memperluas jangkauan pemasaran produk Handcraft.

Media sosial yang dapat dimanfaatkan untuk meningkatkan jangkauan pemasaran produk yaitu berupa facebook, instagram, youtube, dan online shop. Adanya media sosial tersebut dapat dimanfaatkan UMKM untuk dapat mempromosikan produk-produk yang dijualnya. Harapannya dengan adanya media sosial ini akan mampu menjangkau konsumen potensial lebih luas lagi yang kemudian akan mampu meningkatkan omset penjualan sehingga pendapatan dari usaha handcraft tersebut semakin meningkat. Peningkatan pendapatan ini diharapkan akan meningkatkan kesejahteraan pemilik UMKM Handcraft. 
Luaran yang diharapkan dari kegiatan pengabdian kepada masyarakat ini adalah terciptanya media promosi produk sebagai sarana pemasaran serta meningkatnya pengetahuan dan keterampilan pemilik UMKM dalam pemanfaatan media sosial sebagai strategi meningkatkan jangkauan pemasaran produk handcraft.

\section{METODE PELAKSANAAN}

Sesuai dengan permasalahan mitra, bahwa permasalahan yang terjadi di UMKM Handcraft di Desa Babakanmulya adalah kesulitan dalam media pemasaran dan masih rendahnya kompetensi Sumber Daya Manusia (SDM) dalam memanfaatkan media sosial sebagai sarana dalam memasarkan produk handcraft. Oleh karena itu metode yang digunakan dalam kegiatan pengabdian kepada masyarakat ini berupa pelatihan dengan menggunakan metode ceramah, diskusi, dan praktek.

Tahapan pelaksanaan kegiatan pengabdian kepada masyarakat ini dapat dijelaskan sebagai berikut:

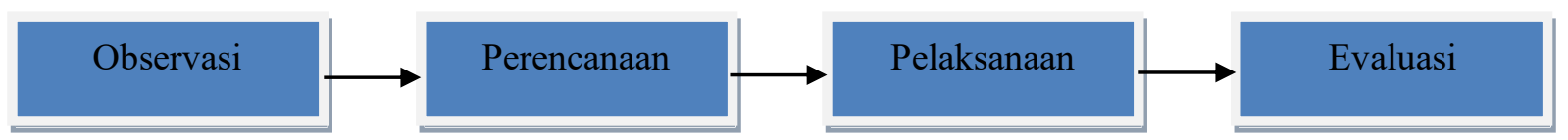

Gambar 1. Tahapan Kegiatan Pengabdian Kepada Masyarakat

\section{Tahap Observasi}

Pada tahapan ini penulis melakukan observasi awal terkait informasi yang dibutuhkan dalam kegiatan pengabdian kepada masyarakat sesuai surat tugas yang dikeluarkan oleh LPPM Universitas Kuningan sebagai jawaban dari adanya Surat Permohonan dari Desa Babakanmulya.

\section{Tahapan Perencanaan}

Pada tahap ini dipersiapkan materi-materi yang akan disampaikan kepada UMKM, membuat konsep vidio pemasaran, membuat desain foto produk, penyiapan sarana prasarana, penentuan media dan model untuk promosi produk dll.

\section{Tahapan Pelaksanaan}

Tahapan selanjutnya dalam kegiatan pengabdian kepada masyarakat ini yaitu tahap pelaksanaan. Pelaksanaan kegiatan pengabdian kepada masyarakat ini dilakukan dengan bentuk pelatihan. Pelatihan ini dibagi menjadi 2 (dua) sesi. Pada sesi pertama disampaikan pelatihan terkait materi materi tentang media sosial, pada sesi ini juga dibahas mengenai manfaat media sosial dalam mempromosikan produk UMKM. Sedangkan pada sesi kedua yaitu praktek penggunaan media sosial. Pada sesi ini dilakukan praktek dalam menggunakan beberapa media sosial, pengambilan shoot foto produk dll.

\section{Tahapan Evaluasi}

Tahapan selanjutnya dalam kegiatan pengabdian kepada masyarakat ini adalah tahap evaluasi. Evaluasi yang dilakukan terkait tingkat pemahaman dan kompetensi yang diperoleh peserta selama kegaiatan berlangsung dengan menggunakan bantuan kuisioner. 
Adapun paradigma dari kegiatan pengabdian kepada masyarakat sebagai berikut:

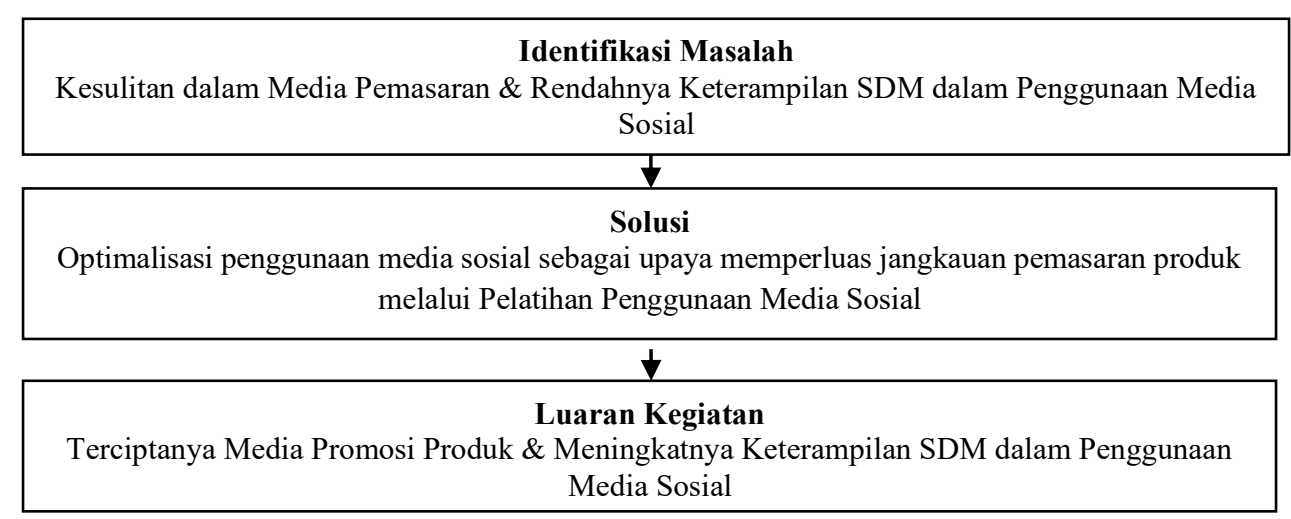

Gambar 2. Paradigma Kegiatan Pengabdian Kepada Masyarakat

\section{HASIL DAN PEMBAHASAN}

Pelaksanaan kegiatan pengabdian kepada masyarakat berlangsung selama 3 hari bertempat di kediaman pengarajin Handcraft Desa Babakanmulya Kecamatan Cigugur Kabupaten Kuningan Jawa Barat. Pelaksanaan kegiatan pengabdian kepada masyarakat ini berjalan dengan baik dan lancar terbukti dari antusias peserta yang terlihat dari keaktifan peserta selama kegiatan ini berlangsung.

Pelaksanaan kegiatan pada hari pertama yaitu pemberian materi terkait media sosial. Pada tahapan ini juga diberikan pemahaman berupa penting nya peranan media sosial dalam upaya memasarkan produk handcrafft.

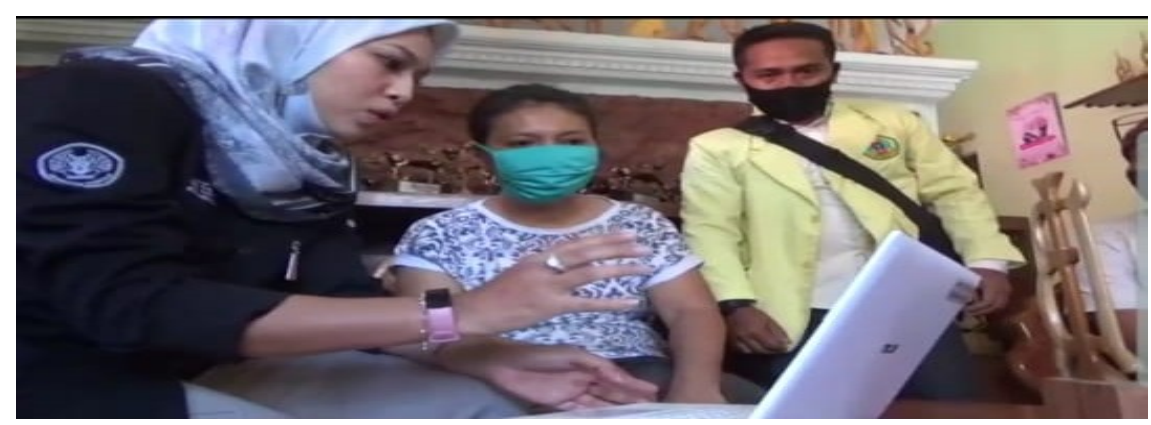

Gambar 3. Penyampaian Materi Media Sosial

Selanjutnya dilakukan kegiatan praktek penggunaan media sosial. Media sosial yang digunakan yaitu facebook, instagram, online shop, dan youtube. Pada tahap ini juga dilakukan praktik teknik mengambil foto/gambar produk agar memiliki nilai estetika dan nilai jual yang sangat penting untuk dijadikan media promosi produk handcraft. 


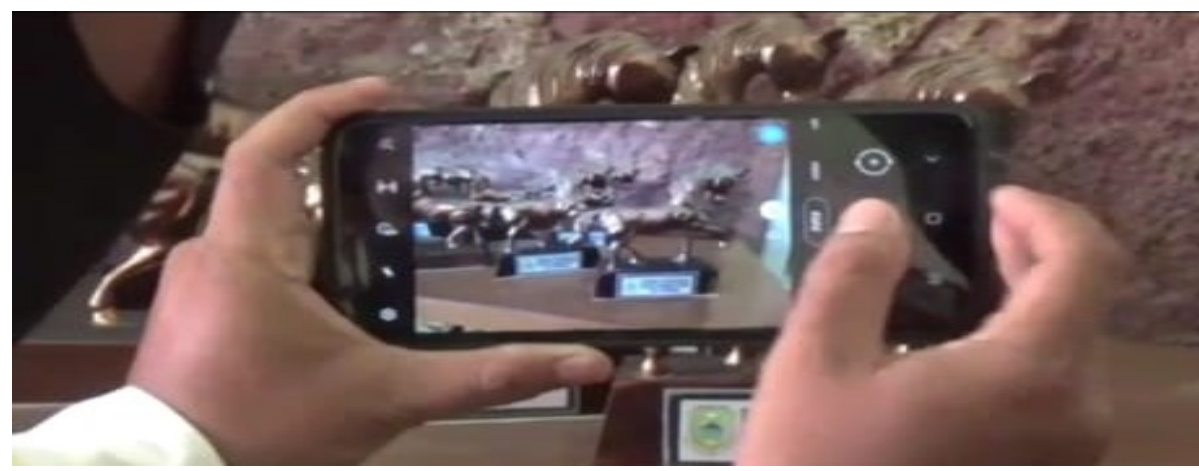

Gambar 4. Praktik Pengambilan Gambar Produk

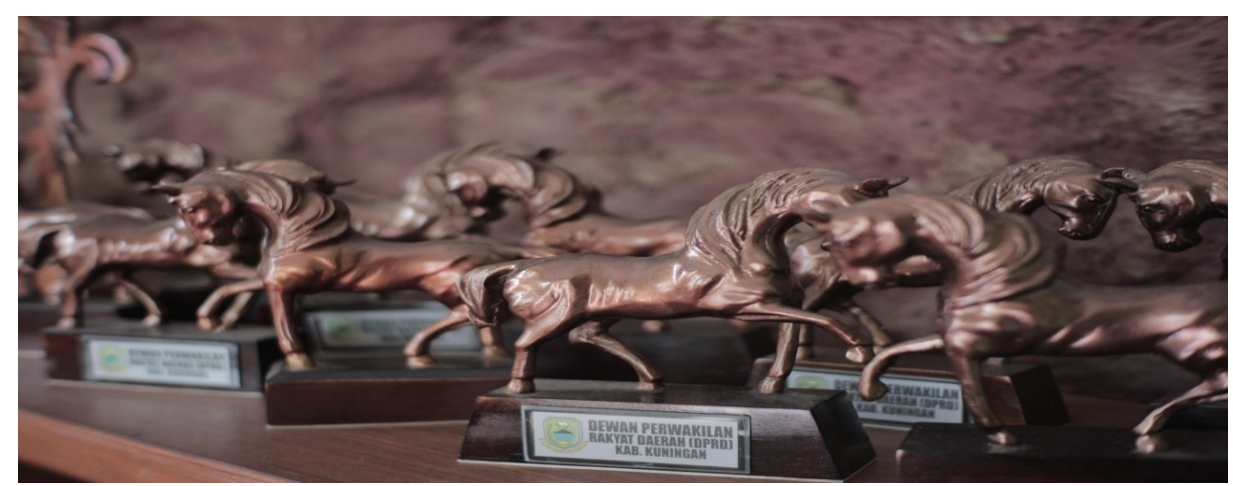

Gambar 5. Contoh Hasil Pengambilan Gambar Produk

Setelah dirasa cukup dalam praktik pengambilan foto atau gambar produk, tahapan selanjutnya yaitu mempraktikan penggunaan media sosial baik facebook, instagram, online shoop, maupun youtube.

Pada tahap ini peserta diberikan kesempatan untuk mempraktekan secara langsung penggunaan media sosial. Peserta sangat antusias dalam mempraktekan penggunaan media sosial karena hal ini merupakan hal baru yang mereka dapatkan. Selama tahapan ini berlangsung, feedback positif dari peserta sangat benar-benar dirasakan. Mereka merasa peran media sosial akan sangat berpengaruh dan membantu dalam memperkenalkan produk mereka kepada konsumen potensial secara lebih luas.

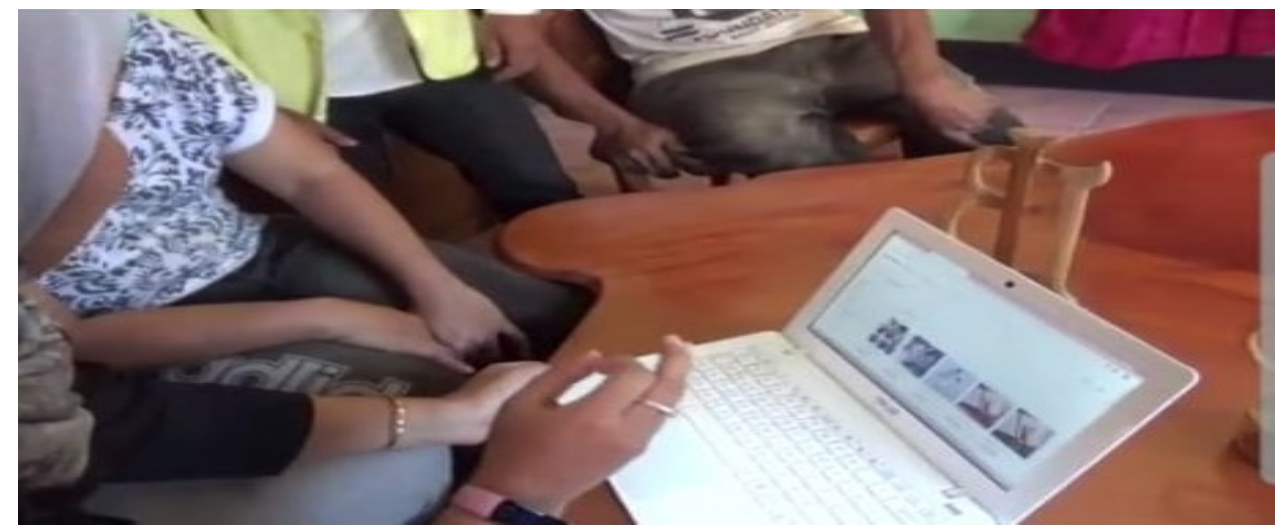

Gambar 6. Praktek Penggunaan Media Sosial

Pada hari kedua kegiatan pengabdian kepada masyarakat juga dilakukan pembuatan vidio shoot untuk mempromosikan salah satu pengrajin dan produk handcraft di desa Babakanmulya bernama pak Udin Kibro sebagai contoh dalam pembuatan vidio promosi melalui youtube. Link youtube dapat diunduh pada https://www.youtube.com/channel/UCTzx6AuU6li3QIi5OlPps-Q. 
Selanjutnya pada hari terakhir pelaksanaan kegiatan pengabdian kepada masyarakat dilakukan evaluasi kegiatan. Pada tahap ini peserta di evaluasi terkait pemahaman dan kemampuan menggunakan medsos melalui kuisioner yang diberikan agar hasil evaluasi tersebut dapat benar-benar terukur sehingga hasil kuisioner tersebut dapat dijadikan pedoman untuk membuat langkah dan strategi selanjutnya dalam upaya peningkatan kapasitas UMKM handcraft di Desa Babakanmulya. Hasil kuisioner menunjukkan $90 \%$ peserta telah memahami dan mampu dalam menggunakan media sosial sebagai upaya dalam media mempromosikan produk handcraft.

Pada akhir kegiatan dilakukan promosi melalui media massa baik cetak maupun online untuk mengexpose kegiatan pengabdian kepada masyarakat yang dilakukan di Desa Babakanmulya khususnya pada UMKM Handcraft sebagai salah satu upaya untuk dapat lebih mengenalkan handcraft sebagai produk unggulan Desa Babakanmulya. Pihak Desa sangat antusias dan sangat mendukung kegiatan ini. Pihaknya berharap kegiatan seperti ini akan terus berlanjut dan terus di monitoring secara continue.

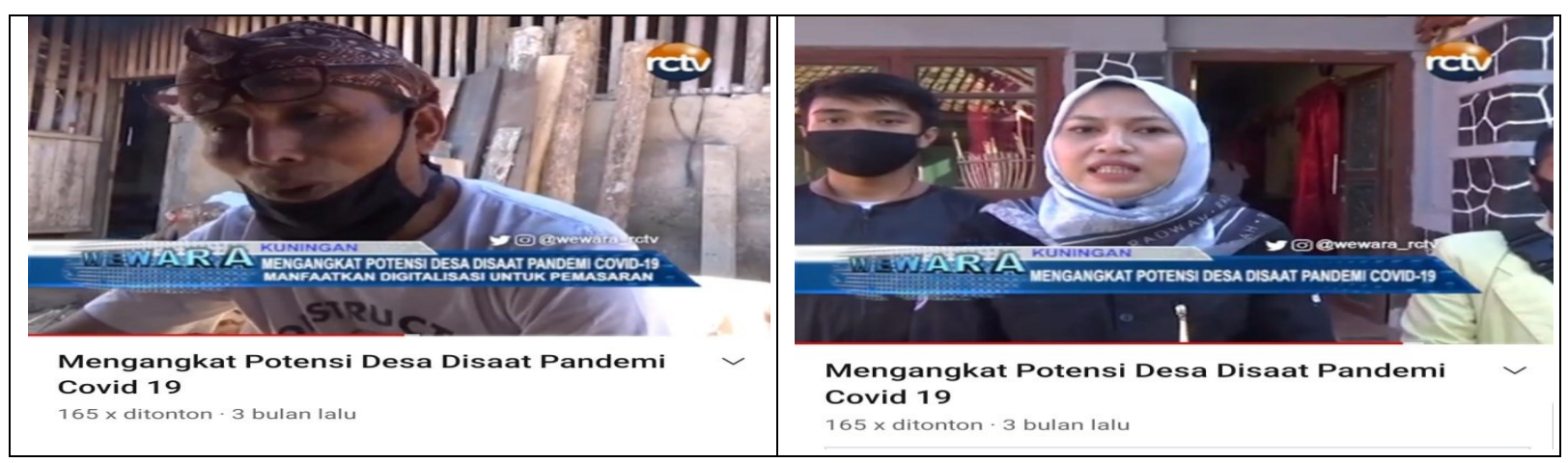

Sumber: https://www.youtube.com/watch?v=w1y-BJqChEQ\&feature=youtu.be

Gambar 7. Pemberitaan Kegiatan Pengabdian Kepada Masyarakat

Dalam praktiknya kegiatan pengabdian kepada masyarakat ini mengalami beberapa hambatan namun hambatan-hambatan tersebut dapat teratasi dengan baik. Kegiatan ini berhasil menghasilkan luaran sesuai dengan tujuan awal berkat dukungan dari semua pihak terutama pihak Desa Babakanmulya. Selain itu, antusiasme peserta yang sangat tinggi menjadikan kegiatan pengabdian kepada masyarakat ini berjalan dengan hidmat dan sukses.

\section{KESIMPULAN DAN SARAN}

\section{Kesimpulan}

Berdasarkan hasil kegiatan yang telah dilaksanakan maka dapat ditarik kesimpulan sebagai berikut:

1. Pelaksanaan kegiatan pelatihan penggunaan media sosial berlangsung lancar, baik dan responsif.

2. Terciptanya media promosi produk sebagai sarana pemasaran serta meningkatnya pengetahuan dan keterampilan pemilik UMKM dalam pemanfaatan media sosial. Hal ini terlihat dari hasil kuisioner yang menunjukkan $90 \%$ peserta telah memahami dan mampu dalam menggunakan media sosial sebagai media mempromosikan produk handcraft.

\section{Saran}

Pelaksanaan kegiatan pengabdian kepada masyarakat dengan metode pelatihan penggunaan media sosial sebagai upaya memperluas jangkauan pemasaran produk perlu dilakukan kepada mitra lain yang tidak hanya berdomisili di Desa Babakanmulya saja tetapi pada seluruh warga masyarakat di 
desa lainnya agar mampu terciptanya desa mandiri yang memiliki One Village One Product (OVOP) sehingga setiap desa mampu meningkatkan kesejahteraan keluarga dengan berwirausaha mengembangakan potensi desanya masing-masing.

\section{UCAPAN TERIMA KASIH}

Penulis mengucapkan terimakasih kepada semua pihak (Pimpinan Universitas Kuningan, LPPM Universitas Kuningan, Pemerintah Desa Babakanmulya, Pengrajin Handcraft Desa Babakanmulya) yang telah membantu terlaksananya kegiatan pengabdian ini.

\section{DAFTAR PUSTAKA}

Kotler, Philip. 1998. Manajemen Pemasaran: Analisis, Perencanaan, Implementasi dan Pengendalian, (Alih bahasa: Hendro Teguh, dan Ronny A. Rusli) Jilid 2, Jakarta. Prenhalindo

LPPM. 2020. Panduan Pengabdian Kepada Masyarakat. Universitas Kuningan

Nasrullah, R. (2015). Media Sosial. Bandung: Simbiosa Rekatama Media.

Puspitarini (2019). Pemanfaatan Media Sosial Sebagai Media Promosi. Jurnal Common Vol. 3 Nomor 1, Juni 2019.

Sutisna (2001). Perilaku Konsumen dan Komunikasi Pemasaran. Bandung. PT. Remaja Rosdakarya. 